Discourse and Communication for Sustainable Education, vol. 8, no. 1, pp. 102-120, 2017

\title{
Interrelations in the Development of Primary School Learners' Creative Imagination and Creative Activity When Depicting a Portrait in Visual Art Lessons
}

\author{
Aleksandra Šlahova \\ Daugavpils University \\ Ilze Volonte \\ Daugavpils Russian Gymnasium \\ Māris Čačka \\ Daugavpils Mark Rothko Art Centre
}

\begin{abstract}
Creative imagination is a psychic process of creating a new original image, idea or art work based on the acquired knowledge, skills, and abilities as well as on the experience of creative activity.

The best of all primary school learners' creative imagination develops at the lessons of visual art, aimed at teaching them to understand what is beautiful in art, as well as through their being involved in the creative process and creating art works themselves.

This paper provides the characterization of the psychological process of imagination, and deals with the importance and dynamics of the development of primary school learners' creative imagination in lessons of visual art when depicting a portrait, and it also looks at a visual art teacher's role in organizing the educational process of developing learners' creative imagination in a sustainable education process.
\end{abstract}

Keywords: creative imagination, the development of creative imagination, primary school learners, visual art lessons, sustainable education.

\section{Introduction}

The problem of the influence of creative imagination on learners' creative activity in visual art lessons is topical due to the fact that it is one of the most necessary cognitive processes for artistic creativity (Hibnere, 1998; Nilson, Fetherston, McMurrey, \& Fetherston, 2013), exercising influence on the whole pedagogical process (Shank, 2016).

The development of creative imagination is important not only as a component of any form of learner's creative activity, but also as that of his behavior in general. The pedagogical practice shows that a creative personality carries out all tasks with enthusiasm, is very self-dependent and responsible, and very actively seeks for and solves demanding problems. 
The problem of the development of learners' creative imagination in visual art lessons has been discussed in scientific works by Nikolajeva (Николаева, 2006), Vigotsky (Выготский, 2005, 1997a, 1997b), Nikolajenko (Николаенко, 2005), Rogov (Рогов, 2001), Hibnere, \& Grasmane (2000), Kuzin (Кузин, 1999), Hibnere (1998). They deal with the nature of imagination, methodological techniques of developing learners' creative imagination and methods of introducing them to art through the development of a creative activity.

Nevertheless, in psychology and pedagogy this problem has not yet been properly studied. Little research has been done on the role of imagination in the field of education (Liang et al., 2012) and visual technologies. In pedagogical practices of teaching visual art, the criteria for assessing the development of creative imagination in its interconnection with improving the constantly stable development of creative activity have not yet been established, and visual art teacher's role in organizing the educational process within sustainable education context has not been defined as well.

Scholars and pedagogues of Latvia have conducted serious research on clarifying the nature of sustainable education (Pipere, 2016; Badjanova, \& Iliško, 2015; Salìte, 2015; Iliško, Skrinda, \& Mičule, 2014; Iliško, Ignatjeva, \& Mičule, 2011; Salìte, 2008; Iliško, 2007; Salīte, Mičule, Kravale, Iliško, \& Stakle, 2007; Salīte, Drelinga, Iliško, Zarina, \& Oḷehnoviča, 2016), and they maintain that education developed within the context of sustainability displays a constant tendency for the development within a long period of time, which is especially vital for aesthetic education as well.

The aim of this research is to establish the dynamics of the development of primary school learners' creative imagination during the process of creative activity in visual art lessons, when depicting a human portrait, and to define the visual art teacher's role in this process within the context of sustainable education.

Research methods: theoretical analysis of scientific literature on the problem under the researched; studying primary school learners' creative works by carrying out a test on establishing the dynamics of the development of creative imagination.

\section{A General Characterization of Imagination Process}

Imagination (fantasy) is a psychic process during which new images, conceptions, ideas are created or already familiar images are updated. Imagination implies a creative inventing, inventing of something unobserved before (Kondrova, 2011; Николаева, 2006; Skujina, 2002; Кузин, 1999).

Imagination is characteristic of human beings only, and is a necessary prerequisite of their life (Hibnere, 1998), it is a human instrument for understanding experience (Nucho, \& Vidnere, 1999, p. 31). Imagination enriches the human mind, since without it human observations and experience are imperfect and limited (Hibnere, \& Grasmane, 2000, p. 195). Consequently, we can say that imagination also influences a human's everyday behavior, a human's mood, even a human's feelings. Sotenloer maintains that active inner power of imagination is an essential means for a human's emotional and spiritual growth (Шоттенлоэр, 2001, p. 18).

Imagination is always based on elements of actually existing objects, which are being transformed into different new combinations by imagination (Hibnere, 1998; Выготский, 1997a). According to S. Rubinstein, imagining implies transforming (Рубинштейн, 2000, p. 317). 
This phenomenon was originally described by Rogov, saying that imagination is the ability to summon up from the wealth of memories in one's consciousness definite components and combine them with new images, and after that build new psychological structures. Imagination is a process of reflecting actual reality (Рогов, 2001, p. 279).

However, Rubinstein maintains that imagination may reflect not only actual reality, but, anticipate the future, a may also create an image, a picture of something that has never existed (Рубинштейн, 2000, p. 319).

Imagination is a very complicated psychic process which closely relates to creative thinking. Imagination is an integral component of a thinking process, and, like thinking, it helps to represent the ulterior function in situations when a new solution has to be found. Before producing a real solution, the action takes place in imagination. With the help of imagination, this pre-emptive action in consciousness is performed with bright images (Hibnere, 1998; Kondrova, 2011).

Imagination is strongly related to memory as well. Imagination differs from memory in the fact that the function of memory is to keep the images and outcomes of an action of previous experience as intact as possible, while the function of imagination is transforming them (Рубинштейн, 2000, p. 318). In other words, imagination is firmly rooted in the content of our memory (Выготский, 1997b, p. 75). Both memory imagination and fancy imagination are creative products of mind (Ozolina Nucho, \& Vidnere, 1999, p. 33).

The majority of authors relate the mechanism of imagination to the development of a personality's practical activity, to the acquisition of such creative kinds of activity as constructing, music, literature, visual art a. o. These kinds of creative activity involve imagining the end products before creating them, as well as thinking about with what kinds of activity these outcomes could be reached (Kondrova, 2011).

The important role of imagination in the development of a creative activity was pointed out by Vigotsky, stating that imagination contributes to shifting the new things into the very flow of our impressions and transforming these impressions so that in the results some new, previously non-existent image emerges (Выготский, 2005, p. 636). As a result of imagination, the rejection of previous experience occurs, i. e. the transformation of the existent experience into the birth of new images, being products of a human's creative activity (Рубинштейн, 2000; Liang et al., 2012).

However, the transformation of reality in one's imagination is not a purely arbitrary transformation, it has its own regular ways, manifested in various techniques of transformation. One of these techniques is combining, blending the elements given in the experience into new, more or less necessary, combinations (Рубинштейн, 2000, p. 328).

Vigotsky (Выготский, 1997a, pp. 6-13) draws attention to the regularity of a psychological mechanism of imagination in a creative activity, relating imagination to reality, and shown schematically in Figure 1.

Figure 1. Mechanism of imagination in a creative activity (the scheme adapted from Vigotsky's theory (Выготский, 1997, pp. 6-13))

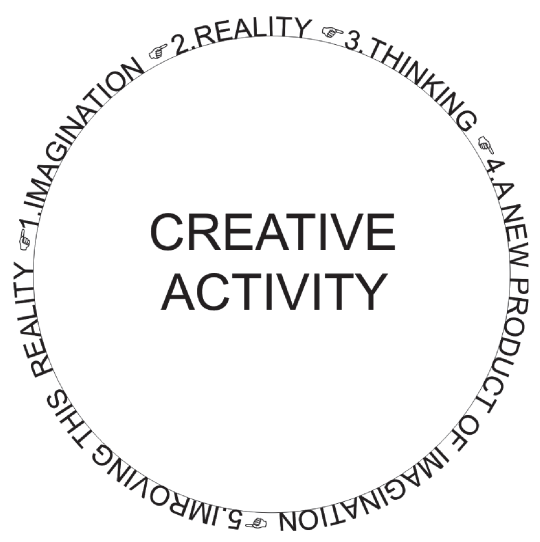


The drawing shows that during its development the product of imagination (1) describes a circle. The elements which these products are built of have been taken by a human from reality (2). In a human's thinking (3), they have undergone a thorough processing and have become a new product of imagination (4). Being finally embodied, they have come back to reality again, but they have returned with a new active force improving this reality (5).

In this way, there is a full circle made by imagination during a creative activity, and it is unbroken, stable and constant in its development.

The same complete circle is also possible in the field of a human's emotional imagination, and it is not hard to imagine it. Vigotsky maintains that when imagination makes a complete circle, both factors - intellectual and emotional - appear to be equally necessary for the act of creation.

\section{Types of Imagination}

Pedagogy and psychology offer a great number of different approaches to and classifications of types of imagination. For instance, the book by Nucho and Vidnere (1999) mentions visual, sound, kinetic, smell, taste and tactile imaginations (p. 31). Nikolajeva, in turn, distinguishes two basic types of imagination defining them as plastic (external) and emotional (internal) ones. Plastic imagination basically employs information provided by external impressions, it builds the image out of elements taken from outside; emotional imagination, on the contrary, - from elements taken from inside (Николаева, 2006, р. 54).

In his monograph, Kuzin (Кузин, 1999, p. 228) speaks about involuntary and voluntary imagination. In case of involuntary imagination, images and ideas emerge without any special human's intention, while in the case of voluntary imagination they appear as a result of a special intention to create something specific. Relating imagination to the images of memory, Kuzin distinguishes two more types of imagination: re-creative and creative, emphasizing that these two types of imagination are tightly interrelated and directly make a considerable impact on the development of creative activity; the same is underlined by Vigotsky (Выготский, 2005, р. 636).

On the basis of theoretical studies, Kondrova (2011) also speaks about unintentional (passive) and intentional (active) types of imagination, but discusses and characterizes their functions in more detail.

Unintentional imagination emerges when the activity of consciousness is low or is disturbed:

- The most frequent variant - dreams you have in your sleep;

- Disorders of consciousness create such type of imagination as nightmare;

- Toxic substances and drugs induce hallucinations.

Intentional imagination is aimed at tackling creative or personal tasks:

- Re-creative or reproductive imagination is based on experience and manifests itself in re-combination of what has been previously perceived;

- Anticipation or prognosticating is modelling of the future;

- Creative imagination - new images and ideas, specific original products of activity are created by a human himself (Kondrova, 2011). 
Move so that there is the order: Hibnere, the Latvian scientist and art pedagogue, maintains that re-creative (reproductive) and creative (productive) imaginations play an especially important role in learners' creative activity (Hibnere, 1998, p. 99).

According to Vigotsky, reproductive imagination implies the same memory which is involved when a human reproduces in one's consciousness several images experienced by him, but he reproduces them at the time when there are no direct reasons for reproducing them. For instance, when drawing some landscape, the artist recalls some other, similar, landscape he has seen previously, i.e. a specific landscape summons up a previously experienced image (Выготский, 2005, p. 636). Reproductive imagination is a rich source for the conceptions of learners' creative activity. When depicting the conceived images in a drawing, some form or application, a learner's psychic activity is especially intense. For the images of consciousness to be distinct enough, a learner strains both his memory and thinking, and also takes a definite emotional attitude towards the phenomenon, which can be a situation depicted (Hibnere, 1998, p. 99).

Creative imagination is a creative conception, the invention of something new, and the forestalling visualization of the conception. Creative imagination is one of the most indispensable cognitive processes of artistic creative activity (ibid., p. 165).

Creative imagination takes an essential place in all kinds of human creative activity, and is the most outstanding personality achievement (ibid., p. 100). Creative imagination enhances the development of learner's artistic creative activity and is strongly related to fantasy, dreams and intuition.

Fantasy is an artistic fiction based on a personality's ability to freely combine images emerging in sub-consciousness, while imagination is a mental cognitive process (Nucho, \& Vidnere, 1999; Рогов, 2001). Dream is the imagination directed towards the future, towards the prospects of a human's life and activities. Dream is one of the factors stimulating the creative search and the development of creative activity not only of a learner, but also those of an adult (Николаева, 2006; Рогов, 2001; Кузин, 1990). Intuition is knowledge which a human has, being unaware of the way he has acquired this knowledge. Intuition allows seeing a problem situation in its entirety, making imagination more focused, which leads to prognosticating the future. Besides, knowledge is acquired immediately as the understanding of the whole, through intuition (Николаева, 2006; Liang et al., 2012).

In the case of creative imagination, the creation of new images, which have been neither in the consciousness nor in the previous experience, it comes to the foreground. In case of creative imagination, out of these elements emerge new combinations, though the elements themselves are not new (Выготский, 2005, p. 637). Thus, imagination and creativity are strongly interrelated, however within this relationship the leading role belongs to the reverse dependence: imagination is being formed during the process of a creative activity (Рубинштейн, 2000, p. 323).

Consequently, among all types of imagination, creative imagination takes the most significant place in learners' creative activity. Creative imagination is related to the abilities oriented towards the effectiveness of a creative activity, such as novelty, transformation, quality and the degree of elaboration of the conception. Creative imagination arouses a wish to create something new and mobilizes all efforts for creating this imagery image, idea or object and for implementing the conception into an artistic creative work. 


\section{Peculiarities of the Development and Influence of Imagination on Primary School Learner's Creative Activity}

Psychology and pedagogy maintain that, in general, human's imagination starts developing at the age of three, and remains active throughout the childhood, adolescence and youth. However, only a small number of adults, those who are very talented and creative, possess the ability of imagination. With age, the majority of people get gradually involved in the prose of everyday life and lose the dreams of their youth. Fortunately, imagination does not vanish completely, it appears anew in some aspects of life and creative activity (Николаева, 2006, р. 35) when a creative approach to solving the problem is required.

Every person can be creative. You should only unlock the creative potential and keep it constantly active in the process of a creative activity. In a creative process a personality shapes himself (Alijevs, 1999; Čehlova, 2002; Varzim, 2005). A creative person never tries to perceive reality objectively. His will is oriented towards understanding the subjective sense of reality and he strives to perceive reality in the way he feels it, to make it act through his creations (Keršenšteiners, 1925, p. 23).

The analysis of pedagogical-psychological literature and our experience in scientific research-based teaching of different subjects at school and art school, as well as delivering different courses on art in the art study programs for students, allow drawing a conclusion that a creative activity develops in all stages and at any age of human life, starting with preschool age children, which is called the initial stage of a creative activity, and then followed by the preparatory stage of a creative activity (elementary school pupils class 5-9), reinforcing stage of a creative activity (secondary school pupils), perfecting stage of a creative activity (students in higher education art study programs) and a creative stage (art specialists) (Šḷahova, Savvina, Čačka, \& Volonte, 2007; Čačka, 2009; Šlahova, \& Čačka, 2009; Čačka, \& Šlahova, 2001).

\section{Each stage of a creative activity serves as a basis for the next stage and creates preconditions for the transition from the lower stage of a creative activity to a higher stage. If any stage in this system is missing, it may stop or slow down the development of a creative activity (Čačka, 2009, p. 39).}

Pursuing the aim of this research in greater detail: we will consider the interconnections and peculiarities of the development of creative imagination and its influence on the development of primary school learners' creative activity. Primary school is the first stage in school education, and the stage when the basic knowledge, skills and attitudes are acquired. In Latvia, the period of basic education comprises 9 classes. Basic school includes a primary school (class 1-4) where the learners' creative activity is at the preparatory stage, and then gradually developing, in classes 5-9, pass to the development stage.

The primary school age is an especially favourable period for beginning a serious and systematic work on the development of imagination and shaping learners' views about a creative activity (Мелик-Пашаев, 1995). Starting school marks, a qualitatively new stage in the development of learners' imagination. The imagination is enhanced by broadening their knowledge and giving them creative and original tasks to fulfil (Кузин, 1999; Николаева, 2006). This process is made even more effective and the development of imagination is even more enhanced by constant creative activities in the circle of their family (with parents, grandparents, sisters and brothers) and out-of-school activities in various forms of interests and education. 
All learners are talented and therefore work with primary school children is aimed at preserving and developing their talent. Naturally, at the primary school age, a learner has already gained certain experience, and has some skills and attitudes, however all activities have to be perceived and interpreted as a game which requires a methodologically-directed continuation of the "game's" action, though even in this period it is already clear that any learner's activity is creative (Мэй, 1995; Alijevs, 1999; Csikszentmihalyi, 1999; Howe, 1999; Ландау, 2002; Lubart, \& Georgsdottir, 2004).

A typical feature of a junior pupil's creative activity is its being based on concrete objects. However, gradually when growing older, instead of relying on objects or actions they start relying on a word, which gives the opportunity of creating a new image in one's mind, through one's imagination (Матюхина, Михальчик, \& Прокина, 1984, p. 237).

At this stage, the learner's sense of form and line is perfected. Compared to the creative manifestations at the primary school age, gradually the need now arises to show not only the specific features of the depicted object, but also the formal relations between its parts. The scientific studies and pedagogical practice show that, little by little, primary school learners start supplementing the so called X-ray or schematic drawing of a human, acquired at the pre-school age, with drawings of a human torso, which ears, hair, hands, and palms with the fingers spread (ibid., p. 238).

Up to the age of $8-9$, in their drawings, learners depict a human body either as rectangular or round, and a head is often disproportionately large. Up to the age of 1011, they represent human faces full-face and in profile only if required. As they grow older, the dimensions of a head in relation to the size of a torso grow proportionally smaller (Николаенко, 2005, p. 148). 10-12-year-old children are able to sketch a human figure in different positions and various movements, which testifies to the fact that learners have started to analyze imaginary objects, unintentionally paying attention to proportional relations between parts of the body (Hibnere, 1998, p. 77). According to many scientists, such changes in learners' creative works can be attributed to the peculiarities of the development of imagination and activity of thinking, as well as to the interrelations between perception and thinking which exist at this age. For them, the element of analysis prevails, while synthesis is behind analysis for the time being (Матюхина, Михальчик, \& Прокина, 1984, р. 238).

In primary school, an emotionally more attractive and significant educational material is being reduced more successfully, since at this period emotion cannot yet be separated from their cognitive processes - perception, memory, thinking and imagination. Primary school learners' visual-imaginary memory and creative imagination are much better developed than their verbal-logical memory (Мелик-Пашаев, 1995; Jurgena, 2001).

At the age of 11 (basically), they reach the stage of "a true picture" and demonstrate their ability to represent the object spatially, and a real drawing in the true sense of the word appears. At this age, the development of learners' spatial concepts, perception and visual imagination about the placement of objects in a three-dimensional space should be enhanced (Выготский, 1997a; Hibnere, 1998). Learners should also be involved in creating and analysing different spatial objects, as well as representing the created spatial object in plane.

During the process of education, when the ability of managing one's own mental activity generally develops, imagination also becomes a manageable process, and images 
created by it appear in tasks set before learners by the content of educational activity (Матюхина, Михальчик, \& Прокина, 1984, рр. 239-240).

A great number of pupils like drawing, but there are only a few who would like to become professional artists. If we compare 6-7-year-old learners with 15-year-old ones, it turns out that 15-year-old pupils are involved in creative activities 2-3 times less (Ананьев, 1999, p. 456). Naturally, there are exceptions. If at the age of 6-7 learners get interested in such activities, their interest in art may not flag until the age of 15 .

If primary school learners' creative activity has been passive, it should be activated anew at teenagers' age, however, quite frequently it turns out to be too late already, since teenagers' interests and activities take various directions in social life, and it depends on teenagers' physiological development as well. This transitional age is known to be critical, and the activity of imagination, in the way it manifests itself in childhood decreases during adolescence (Выготский, 1997a; Hibnere, 1998; Feist, 1999; Eisner, 2002).

At this stage, learners start feeling doubtful about their abilities, and a decrease in their creativity is observed, which, of course, has to be attributed to the age peculiarities (Выготский, 1997a; Lubart, \& Georgsdottir, 2004). This situation is usually coped with only by particularly gifted children or by those for whom teaching of visual art at school or special conditions at home create favorable preconditions for a further development of visual art abilities.

From the age of 11 and up to the age of 15-16, learners go through the analyticalassessing stage when visual perception plays the principal role. Therefore, a teenager strives for representing a real and natural form, and takes his failures to heart. They wish to depict what they have seen as it is in reality - realistically, however, as the pedagogical practice proves, many teenagers like to represent everything graphically, minimally applying colour (Аранова, 2004, p. 32).

At primary school age, learners' inquisitiveness rapidly grows, new questions, which are oriented towards the past and the future, arise. According to Svence, a teenager is able to consider complicated, and abstract ideas, compare alternatives, and independently seek for what is new and unusual (Svence, 1999, p. 127). Teenagers still better perceive things they can imagine. To understand concepts is still difficult for them, but they already demonstrate critical thinking, since such exclamations as "I don't believe what is written in books, in life it is different!" are often given (Jurgena, 2001, pp. 81-82). I myself decide what I wish to want, according to the criteria I establish myself (Gudjons, 2007, p. 153). Virtual environments, social communication and opportunities of rapid communication make a great impact on the contemporary generation as well.

At the primary school age, the development of imagination changes and develops rapidly, and at the age of 12-14 it reaches a maximal increase. At this stage, learners can already represent transformations in perspective and show movements by means of lights and darks. Imagination is hindered, if learners are overburdened with a great amount of specific information. The more rapidly the scope of knowledge expands, the quicker imagination diminishes (Hibnere, 1998). Therefore, for a more seminal development of learners' creative activity in close interconnection with organizing a creative activity, an individual approach to every learner is needed during the educational process.

To conclude this section, we would like to point out a special importance of developing learners' creative imagination in interrelation with promoting a creative activity at a school age, since imagination plays an important role in every creative process. 
This is especially important for the artistic creativity (Рубинштейн, 2000). A properly developed creative imagination is not only a guarantee for a successful development of learner's creative activity, but also a guarantee for the development of all their personal qualities required to organize their future. Vigotsky states that the principal educational perception of pedagogical work must lie in pupil's preparing for the future, and developing learner's imagination is one of the basic forces during the process of achieving this aim (Выготский, 1997a).

\section{The Dynamics of the Development of Imagination During the Process of Primary School Learners' Creative Activity at Visual Art Lessons}

Following the theme above, we will focus on studying the peculiarities of primary school learners' representations of portraits, where the abilities of creative imagination are manifested at their best. A portrait as an art genre is characterized by an in-depth psychological aspect, when in the art work the artist portrays both the person's appearance and inner emotional world.

The studies of scientific literature testify to the fact that until now the dynamics of the development of primary school learners' creative imagination have not yet been studied in pedagogical practice through their creative works on representing portraits.

The practice of employing children's drawings of human figures for assessing learners' intellectual abilities is widely spread among psychologists, practitioners of medicine and pedagogues in many countries. For this purpose, the Goodenough-Harris Drawing Test Draw-a-Man Scoring Guide, developed by two psychologists - Goodenough, Florence and Harris, Dale is usually used. In the test, the system of scoring points has been developed for assessing a drawing with precisely represented details of a human figure: e.g. the reproduction of a great number of parts of a body, articles of clothing and accessories, facial expressions the figure's movements and sex.

By making use of human figure-drawings, many scientists have carried out research on students and adults (Fall, Eaves, \& Woods-Groves, 2006; Dey, \& Ghos, 2016; Khasu, \& Jr, 2016), pre-school age children (Рогов, 2001; Tanka, \& Sakuma, 2004; Maley, 2009; Rehrig, 2015), primary and secondary school learners etc.

These authors have arrived at the conclusion that the use of this type of tests deserves great attention (Tanka, \& Sakuma, 2004), however, results obtained from tests should not be relied on completely (Imuta, Scarf, Pharo, \& Hyne, 2013), and the test should be used very carefully (Khasu, \& Jr, 2016), therefore, the testees have to be prepared as to selection and decision-taking during the experiments (Troncone, 2014). Besides, Rogov comes to the conclusion that these criteria cannot serve as a basis to make conclusions about a child's mental retardation (Рогов, 2001, p. 309).

The analysis of scientific literature allows us in conclude that in order to establish the peculiarities of primary school learners' creative imagination when they fulfil the task "Portrait" at visual art lessons, the test Goodenough-Harris Drawing Test Drawa-Man Scoring Guide can be partially used (Рогов, 2001, pp. 296-309; Maley, 2009, pp. 328-343). For the research on the development of learners' imagination at drawing a human portrait, we have taken, altogether including 73 (71) criteria, criteria 1-23, characterizing the representation of the principal human features from this test. 
Taking into account the methodological recommendations on drawing a human portrait, reflected in the research by Hibnere (1998, pp. 105-109), Nikolajenko (Николаенко, 2005, pp. 146-150), and on the basis of the analysis of primary school learners' creative works, 12 criteria were selected and adapted for the purpose of this research. Indicators of these criteria in drawings were as well designed during the experiment, according to the three levels of creative imagination (Table 1).

Table 1.

Criteria and Indicators in Drawings for Establishing the Level of Learners' Creative Imagination at Representing a Human Portrait (adapted test Goodenough-Harris Drawing Test Draw-a-Man Scoring Guide) (Maley, 2009, pp. 328-343)

\begin{tabular}{|c|c|c|c|c|c|c|c|}
\hline \multirow[t]{2}{*}{ № } & \multirow[t]{2}{*}{ Item } & \multicolumn{2}{|c|}{$\begin{array}{c}\text { Low level } \\
(1 \text { point })\end{array}$} & \multicolumn{2}{|c|}{$\begin{array}{c}\text { Average level } \\
(2 \text { points })\end{array}$} & \multicolumn{2}{|c|}{$\begin{array}{l}\text { High level } \\
\text { (3 points) }\end{array}$} \\
\hline & & Full face & Profile & Full face & $\begin{array}{l}\text { Profile } \\
\end{array}$ & Full face & $\begin{array}{l}\text { Profile } \\
\end{array}$ \\
\hline 1. & $\begin{array}{l}\text { Head present: any clear } \\
\text { method of representing head }\end{array}$ & & & & & & \\
\hline 2. & $\begin{array}{l}\text { Neck present: outline of neck } \\
\text { continuous with that of the } \\
\text { head, of the trunk, or of both. } \\
\text { Line of the neck must "flow" } \\
\text { into head line or trunk line }\end{array}$ & & & & & & \\
\hline 3. & $\begin{array}{l}\text { Eyes present: either one or } \\
\text { two eyes must be shown. Any } \\
\text { method is satisfactory. The } \\
\text { horizontal dimension of the } \\
\text { eye must be greater than the } \\
\text { vertical dimension. Sometimes } \\
\text { in profile drawing of a high } \\
\text { grade the eye is shown in } \\
\text { perspective. In such drawing } \\
\text { any triangular form is credited }\end{array}$ & & & & & & \\
\hline 4. & $\begin{array}{l}\text { Eye detail: pupil. Any clear } \\
\text { indication of the pupil or iris } \\
\text { as distinct from the outline of } \\
\text { eye. Both must appear if both } \\
\text { eyes are shown }\end{array}$ & & & & & & \\
\hline 5. & $\begin{array}{l}\text { Eye detail (brow or lashes): } \\
\text { brow, lashes or both shown }\end{array}$ & & & & & & \\
\hline 6. & $\begin{array}{l}\text { Nose present: any clear } \\
\text { method of representation. Full } \\
\text { face: credit all attempts to } \\
\text { portray the nose in two } \\
\text { dimensions, when bridge is } \\
\text { longer than the width of the } \\
\text { base or tip. Profile: credit all } \\
\text { crude attempts to show the } \\
\text { nose in profile, provided tip or } \\
\text { base is shown in some manner. } \\
\text { Do not credit simple „button" }\end{array}$ & $\stackrel{\bullet}{\Delta}$ & 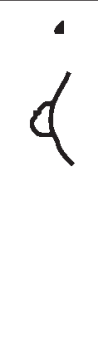 & (1) & & & $\zeta$ \\
\hline
\end{tabular}

Sequel to Table 1 see on the next page. 
Sequel to Table 1.

\begin{tabular}{|l|l|l}
\hline 7. & $\begin{array}{l}\text { Bridge of nose. Full face: } \\
\text { placement of upper portion of } \\
\text { bridge is important, must } \\
\text { extend up to or between the } \\
\text { eyes. Bridge must be narrower } \\
\text { than the base. Profile: } \text { Nose at } \\
\text { angle with face, approximately } \\
\text { 35-45 degree. Separation of } \\
\text { nose from forehead clearly } \\
\text { shown at eye }\end{array}$ \\
\hline $\begin{array}{l}\text { Lips: Any clear representation } \\
\text { 8. }\end{array}$
\end{tabular}

The dynamics of the development of learners' imagination is established by three levels according to the points given:

- A low level of the development of imagination (1-12 points). If the level of creative imagination is low, the majority of learners represent a human portrait schematically, and drawings, as a rule, are primitive and with stereotyped schemes present.

- An average level of the development of imagination (13-24 points). At this level, the schematic character of facial elements in learners' drawings gradually disappear facial features take a more specific form.

- A high level of the development of imagination (25-36 points). At a high level, learners' creative imagination produces detailed and, as a rule, original drawings, with highly elaborated elements. 
If any facial element in general is missing in the drawing, for instance, no nose or ears, then this criterion is assessed by 0 points.

It should be emphasized that the above mentioned points are only an approximate reference-point for assessing the development of learners' imagination.

The experiment involved 167 learners from classes 1-9. During a visual art lesson, learners were offered to draw a portrait of a human in pencil or in pen. The teacher did not give any specific instructions on how to draw a portrait. No commentaries were allowed during the fulfilment of the task. Testing was done individually. When the task was done, an additional interview with some learners was held to clarify the uncertain details in the representation of a portrait. On the whole, the results of the experiment in percentage terms are shown in Table 2.

Table 2.

The Level of the Development of Learners' Creative Imagination After the Research (in percentage for every class)

\begin{tabular}{lccccccccc}
\hline Level & $\begin{array}{c}\text { Class 1 } \\
(37)\end{array}$ & $\begin{array}{c}\text { Class 2 } \\
(15)\end{array}$ & $\begin{array}{c}\text { Class 3 } \\
(12)\end{array}$ & $\begin{array}{c}\text { Class 4 } \\
(28)\end{array}$ & $\begin{array}{c}\text { Class 5 } \\
(27)\end{array}$ & $\begin{array}{c}\text { Class 6 } \\
(14)\end{array}$ & $\begin{array}{c}\text { Class } 7 \\
(9)\end{array}$ & $\begin{array}{c}\text { Class } 8 \\
(12)\end{array}$ & $\begin{array}{c}\text { Class } 9 \\
(13)\end{array}$ \\
\hline Low $(\%)$ & 41 & 33 & 42 & 43 & 41 & 16 & 0 & 8 & 0 \\
\hline Average $(\%)$ & 54 & 53 & 29 & 32 & 33 & 36 & 33 & 16 & 46 \\
\hline High (\%) & 5 & 14 & 29 & 25 & 26 & 48 & 67 & 76 & 54 \\
\hline
\end{tabular}

At an average, $25 \%$ of the learners of all classes have a low level, $37 \%$ of the learners - an average level, and $38 \%$ of learners - a high level of the development of creative imagination. The dynamics of the development of learners' creative imagination is graphically shown in the diagram (Figure 2).

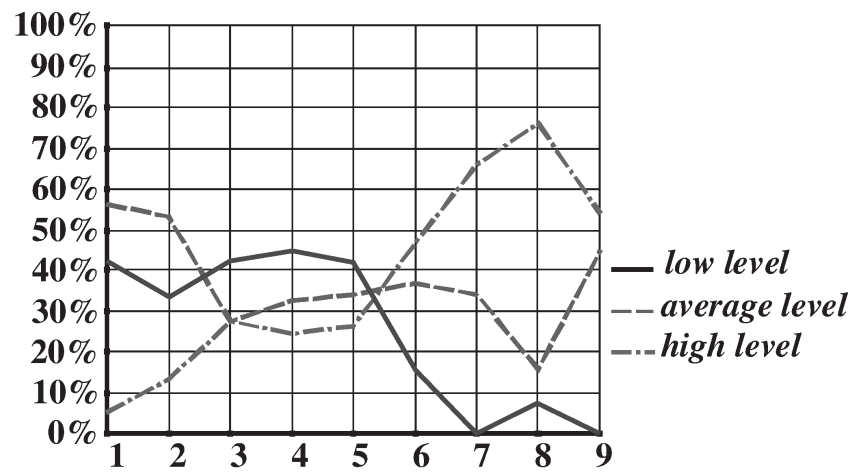

Figure 2. The development of learners' creative imagination level in all classes

Consequently, the outcomes of the test allow us to conclude that at the initial stage of the experiment, in different age groups there are learners with different levels of creative imagination. Moreover, the dynamics of the development of creative imagination by levels when passing from one class to the next one changes, showing the increase of the high level. However, in every class there are still quite numerous learners whose level of creative imagination is either low or average. This shows that to develop learners' creative imagination a special work is required during the process of creative activity in visual art lessons. 


\section{Visual Art Teacher's Role in the Development of Imagination during the Process of Primary School Learners' Creative Activity within Sustainable Education Context}

Visual art is a totality of visually perceptible works of art - a culture value (Hibnere, 1999, p. 187). Visual art as the subject in school (drawing, painting, modelling etc.) promotes learners' purposeful cognitive process and develops their cognitive activity, which are required for learners' further professional growth in the field of art (Кузин, 1999; Liang et al., 2012; Nilson, Fetherston, McMurray, \& Fetherston, 2013). Therefore, all schools need to find a way for the four pillars: Learning to know; Learning to do; Learning to live together; Learning to be able to find their equal place in education (Iliško, Skrinda, \& Mičule, 2014, p. 89).

The basic task of visual art lessons is to stimulate learners' creative imagination and fantasy, and the visual art teacher's aim of these lessons is to create the atmosphere of spiritual freedom and joy of creating art works; a teacher is supposed not only to teach learners how to paint, draw and model, but also has to find methods of how to involve learners in art, how to teach them to work creatively, how to reveal and develop their creative potential in an activity which would be accessible and interesting for learners. Evidently, recipes are hardly acceptable in this case. However, search should be done in all directions (Кларин, 1994; Kincans, 2006), and teacher's proficiency, pedagogical experience and example play a fundamental role in it, because "the teacher's mission is to look at the world and to see more of what is known for society, education and science" (Salite, 2015, p. 27).

Naturally, a visual art teacher has to be an artist with education in art pedagogy, and in the first place use his pedagogical skills in involving learners in art. This implies that teacher's educational work is a creative process and the teacher has a creative personality whose creative freedom cannot be limited by any programs, methodological regulations and study plans (Lind, 2013, p. 152). Th teacher has to be also a researcher (Salite, 2008) in the reforming of the curricula and teaching approaches in their schools (Iliško, 2007).

A teacher can be highly creative in developing materials and approaches that spark children's interests and motivate their learning. The visual art teacher has to take the responsibility and the control of oneself, has to be innovative in "creating a learning environment that would promote interest toward sustainability" (Salite, 2008, p. 14), so that the educational process would enhance the development of every learner's artistic abilities, skills, the development of critical thinking, creative imagination and wish to be engaged in a creative activity (Jeffrey, \& Craft, 2004).

For a teacher, it is important to create such situations where a learner could feel that he is a unique personality, differing from others by his own individual qualities and human value (Pipere, 2016; Badjanova, \& Iliško, 2015). Creation implies creating new results and a new way of fulfilling the task in different conditions, and perhaps completely unexpected ways and tasks are possible (Salite et al., 2007, p. 289), including the content of sustainable education.

The main features of sustainable education are the following: the emphases on the learner and his/her meaningful questions, constructivist modes of learning implemented through the inquiry, a democratic learning community where each participant is involved in active decision-making concerning his/ 
her learning. Education for sustainable development means not only changing the content that we teach, but also the traditional notions about how we teach (Iliško, Ignatjeva, \& Mičule, I. 2011, p. 88).

In education, it is necessary that the idea of sustainability is discovered and accepted in the learners' minds as their personal and interest-sustained idea, where action learning, action research, building a shared vision and decision-making represent the most typical solutions (Salìte, 2008).

As it was said before, any product of imagination is based on actual facts, and on observations. The richer the store of observations is, the more opportunities for using it in the activity of imagination are provided. To successfully develop learners' creative imagination, in every lesson a teacher constantly has to encourage them to demonstrate fantasy, free imagination, since these are fundamental qualities of creative thinking. The accumulation of various impressions, and the development of the power of observation in every lesson are indispensable prerequisites for the development of creative imagination in visual art lessons (Кларин, 1994; Кузин, 1999). Creation always brings joy and surprise (Alijevs, 1999). Creative tasks, first and foremost, have to contribute to removing the "barriers, "while creating, have to provide the opportunity for the learners to ignore instructions and let loose their imagination.

In the lesson, learners must have comfortable working conditions, so that they can work effectively, having no fear that their new idea could be accepted inadequately. Fear is quite a dangerous barrier for people oriented to achieving success. Fear of failure, of public condemnation paralyses imagination, decreases a creative activity, and this leaves a negative impact on the development of a creative personality (Рогов, 2001, p. 296).

Imagination always implies some removal from reality. However, in any case the source of imagination is the objective reality (Кузин, 1999, p. 225). It is impossible to reproduce absolutely precisely a material from: whether you like it or not, the artist depends on his eye, his hand, which are more artistic in this case (Кандинский, 1989, p. 29).

Works of creative imagination enhance learners' activity very much, because at doing such works they are able to maximally express themselves, since the opportunity is provided to visualize one's own individual idea in different art genres, for instance, presenting a landscape or a still life, a human or animal figure, a portrait etc. In a drawing of imagination, familiar objects can be described in an unusual way. Imagining does not imply obligatory deforming a form, but rather from an already familiar image to create new, until now nowhere observed images, devised and imagined by the author, whose depiction in real life is not envisaged or planned (Hibnere, \& Grasmane, 2000, p. 195).

When additional research was carried out after the teacher had done appropriate work on the development of primary school learners' creative imagination during the process of drawing a human portrait, the analysis of the results showed that the levels of learners' creative imagination at passing from one class to the next had changed. On average, in all classes the number of learners with a low level of the development of creative imagination had decreased by $15 \%$, while the number of those with a high level of the development of creative imagination had increased by $29 \%$.

The observation showed that learners liked creative tasks. Such tasks were interesting for them, and they wanted to work not fearing to demonstrate their individuality. Their 
works showed that they had become more serious in respect of this type of tasks. Consequently, we may conclude that visual art lessons qualitatively develop children's imagination, increase their activeness and motivation.

Some qualitative changes can also be mentioned. The learners' need for creation and creativity, being spontaneous, had started to transform into a tradition. The learners began searching for original, non-standard solutions. They no longer looked at a creative lesson as a forced requirement, but rather as a natural and logical continuation of work begun before. Learners put forward their proposals, expressed their wishes, and suggested changes in tasks, which all shows that they had achieved a qualitatively new level of creativity. They created prudentially, for the result in the future, which implies that their creative imagination had also qualitatively changed.

Primary school learners' works can be an example of the above (Figures 3-6). Works by learners of other classes had changed qualitatively too, showing that learners' creative imagination can be influenced by the efficiently organized educational process and work of a visual art teacher.

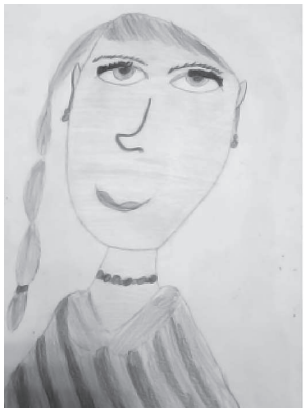

Figure 3. Anna-Marija

(Class 1) (28 points - Level 3)

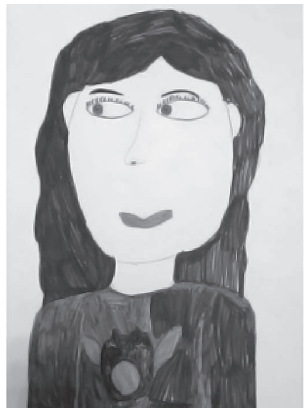

Figure 4.

Brigita (Class 1)

(29 points - Level 3)

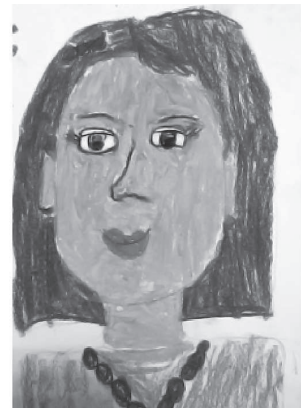

Figure 5.

Ksenija (Class 2)

(33 points - Level 3)

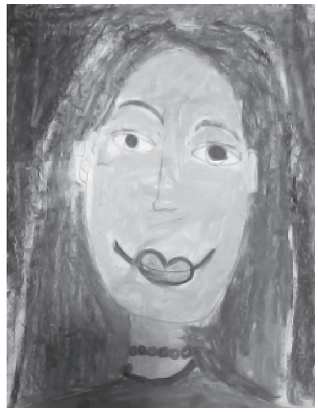

Figure 6. Jana (Class 3 )

(31 points - Level 3)

Our research shows that creativity is natural for learners and they are able and want to be engaged in creative activities. Teacher should only encourage them a little to do it, to support them in their efforts and duly contribute to the development of creative imagination.

\section{Conclusions}

The theoretical and experimental research leads to the conclusion that the development of learners' creative imagination will be successful and adequate within the context of sustainable education, if learners' skills, their creative potential and talent are purposefully developed and a learner-friendly environment is created.

Taking into account the results of the theoretical and empirical research on defining the development of creative imagination during work with primary school learners in visual art lessons, a teacher should purposefully, on the basis of the results of the development of learners' creative imagination, develop learners' creative activity, constantly motivate them for creative work, since creative imagination and a creative activity 
mutually add to each other and mutually develop each other, thus promoting the formation of a creative personality. This can be achieved only through constant and hard work of a teacher, and the teacher's personal example is also an essential prerequisite for this in a sustainable education context.

The test Goodenough-Harris Drawing Test Draw-a-Man Scoring Guide can be adapted not only for identifying the dynamics of the development of learners' creative imagination at drawing a human portrait, but also for drawing a figure in general.

\section{References}

Alijevs R. (1999). Vidusskolènu jaunrade mācībās [Creativity of pupils of high school in training]. Rīga: Raka, 274.

Ананьев, Б. Г. (1999). Задачи психологии искусства [Problems of psychology of art]. Психология художественного творчества: Хрестоматия. Минск: Харвест, 452464.

Аранова, С. В. (2004). Обучение изобразительному искусству. Интеграция художественного и логического [Training to the fine arts]. СПб: КАРО, 176.

Badjanova, J., \& Iliško, Dz. (2015). Holistic approach as viewed by the basic school teachers in Latvia. Discourse and Communication for Sustainable Education, 6, 132-140.

Выготский, Л. С. (2005). Психология развития человека [Psychology of Human Development]. Москва: Смысл; Эксмо, 1136. Revised from http://yanko.lib.ru/books/ psycholvygotsky=ps_pzv_cheloveka=ann.htm

Выготский Л. С. (1997а). Воображение и творчество в детском возрасте [Imagination and creativity in childhood]. СПб: Союз, 96. Retrieved from http://pedlib.ru/Books/ 7/0060/7_0060-1.shtml\#book_page_top

Выготский Л. С. (1997б). Лекции по психологии [Lectures on Psychology]. СПб: Союз, 144.

Csikszentmihalyi, M. (1999). Implications of a systems perspective for the study of creativity. In J Robert, \& J. Sternberg (Ed.) Handbook of Creativity (297-312). Cambridge: Cambridge University Press.

Čačka, M. (2009). The Development of students' creative activity during the process of art studies (PhD thesis). Daugavpils: Saule.

Čačka, M., \& Šl lahova, A. (2011). Peculiarities of the development of interest towards creative activity. Arts and Skills - Source of Well-being. Third International Journal of Intercultural Arts Education. Ruismaki, H., \& Ruokonen, I. (Ed.), Helsinki: University of Helsinki, 31-45.

Čehlova Z. (2002). Izziņas aktivitāte mācībās [Ńognitive activity in education]. Rīga: RaKa, 136.

Dey, A., \& Ghosh P. (2016). Do human-figure drawings of children and adolescents mirror their cognitive style and self-esteem? International Journal of Art \& Design Education, 35(1), 68-85.

Eisner, E. W. (2002). The arts and the creation of mind. New Haven \& London: Yale University Press.

Feist, C. J. (1999). The influence of personality on artistic and scientific creativity. In J. Robert, \& . Sternberg, (Ed.). Handbook of Creativity. (273-296). Cambridge University Press. 
Gudjons, H. (2007). Pedagogiias pamatatzinas [Basic Principles of Pedagogy]. Rīga, Zvaigzne ABC.

Hibnere, V. (1998). Bèrna vizuālā darbība. [Art Activity of Children]. Rīga, RaKa.

Hibnere, V., \& Grasmane L. (2000). Bèrna vizuālà darbība [Child's Visual Activity] Rīga: RaKa.

Николаева, Е. И. (2006). Психология детского творчества [Psychology of Children Creativity]. СПб: Речь.

Николаенко, Н. Н. (2005). Психология творчества [Psychology of Creativity]. Шипицыной, СПб: Речь.

Howe, M. J. A. (1999). Prodigies and creativity. In J. Robert, \& Sternberg (Ed). Handbook of Creativity (392-430). Cambridge: Cambridge University Press.

Iliško, Dz., Skrinda, A., \& Mičule, I. (2014). Envisioning the future: Bachelor's and master's degree students' perspectives. Journal of Teacher Education for Sustainability, 16(2), 88-102.

Iliško, Dz., Ignatjeva, S., \& Mičule, I. (2011). Teacher-carried research as a tool for teachers' professional growth. Journal of Teacher Education for Sustainability, 13(2), 87-103.

Iliško, Dz. (2007). Teachers as agents of societal change. Journal of Teacher Education for Sustainability, 7, 14-27.

Imuta, K., Scarf, D., Pharo, H., \& Hayne, H. (2013). Drawing a close to the use of human figure drawings as a projective measure of intelligence., 8(3). doi:10.1371/ journal.pone.0058991.

Jeffrey, B., \& Craft, A. (2004). Teaching creatively and teaching for creativity: distinctions and relationships. Educational Studies, 30 (1), 77-87.

Jr, T. O. W., Fall, A.-M., Eaves, R. C., \& Woods-Groves, S. (2006). The reliability of scores for the draw-a-person intellectual ability test for children, adolescents, and adults. Journal of Psychoeducational Assessment, 24 (2), 137-144.

Jurgena, I. (2001). Vispārīgā pedagogiija [General Pedagogy]. Rīga: SIA Izglītības solii.

Кандинский, В. (1989). О духовном в искусстве [Аbout the spiritual in art]. Ленинград: ЛОСПС.

Keršenšteiners, G. (1925). Audzinātāja dvēsele un skolotāju izglìtības jautājums [A tutor's soul and the issue of training teachers]. Riga: IZM.

Khasu, D. S., \& Jr, T. O. W. (2016). The score reliability of draw-a-person intellectual ability test (DAP: IQ) for rural Malawi students. Journal of International Education Research - Second Quarter, 12 (2), 61-65.

Kincāns, V. (2006). Mākslas izglītības būtība mūsdienu sabiedrībā [The nature of art education in contemporary society]. Riga: LU Akadēmiskais apgāds.

Кларин, М. В. (1994). Инновационные модели обучения в зарубежных педагогических поисках [Innovative Models of Training in Foreign Pedagogical Searches]. Москва: Арена.

Kondrova, A. (2011). Kognitīuo procesu sistèma [The system of cognitive processes]. Retrieved from http://profizgl.lu.lv/mod/resource/view.php?id=20327

Кузин, В. С. (1999). Психология [Psychology]. Москва: Агар.

Ландау, Э. (2002). Одаренность требует мужества: Психологическое сопровождение одаренного ребенка [Endowments Demand Courage]. Москва: Академия.

Ландау, Э. (2002). Одаренность требует мужества: Психологическое сопровождение одаренного ребенка [Endowments Demand Courage]. Москва: Академия. 
Liang, C., Ze, Y., Hsu, Y., Huang, Y., \& Chen, S.-C. (2012). How learning environments can stimulate student imagination. The Turkish Online Journal of Educational Technology, 11(4), 432-441.

Lichtenstein, M. J., Pruski, L. A., Marshall, C. E., Blalock, C. L., Liu, Y., \& Plaetke, R. (2004). Do middle school students really have fixed images of elders? The Journals of Gerontology B60 (1), 37-S47.

Lind, E. (2013). Possibilities for creative self-actualisation in craft. Differences and similarities in handcraft in the 19th and 21st century in Estonian general education schools. Interdisciplinary Journal for Music and Art Pedagogy, 5 (1),149-159.

Lubart, T. I., \& Georgsdottir, A. (2004). Creativity: Developmental and cross-cultural issues. In Lau, S., Nui, A.N.N., \& Ng, G.Y.C. (Eds.). Creativity: When East meets East. (23-54). World Scientific publishing, Co. Pte. Ltd.,

Maley, C. (2009). Young children's human figure drawings: an investigation using the Goodenough-Harris drawing test and the raseh model for measurement. $\mathrm{PhD}$ Thesis, James Cook University. Retrieved from http:/leprints.jcu.edu.au/11382; http://researchonline.jcu.edu.au/11382/2/02whole.pdf

Матюхина М. В., Михальчик Т. С., \& Прокина Н. Ф. (1984). Возрастная и педагогическая психология [Age and Pedagogical Psychology]. Москва: Просвещение.

Мелик-Пашаев, А. А., \& Новлянская, 3. Н. (1995). Ступеньки к творчеству [Steps to creativity]. Москва: Искусство в школе.

Мэй, Р. (1995). Мужество творить: Очерк психологии творчества [Courage to create. A sketch of psychology of creativity] Москва: Институт общегуманитарных исследований.

Nilson, C., Fetherston, C. M., McMurray, A., \& Fetherston, T. (2013). Creative arts: An essential element in the teacher's toolkit when developing critical thinking in children. Australian Journal of Teacher Education, 38 (7). 43-54.

Ozolina Nucho, A., \& Vidnere, M. (1999). Māksla un pašatklāsme [Art and self-determination]. Riga: AGB.

Pipere, A. (2016). Envisioning complexity: Towards a new conceptualization of educational research for sustainability. Discourse and Communication for Sustainable Education, 7(2), 68-91.

Rehrig, G. L. (2015). Drawing comparisons between drawing performance and developmental assessments (Mg. thesis). New Jersey: New Brunswick.

Рогов, Е. И. (2001). Психология человека [Human Psychology]. Мосkва: Владос.

Рубинштейн С. Л. (2000). Основы общей психологии [Basics of general psychology]. СПб: Питер.

Salīte, I., Drelinga, E., Iliško, Dz., Zariṇa, S., \& Oḷehnoviča, E. (2016). Sustainability from the transdisciplinary perspective: An action research strategy for continuing education course development. Journal of Teacher Education for Sustainability, $17(2), 135-153$.

Salīe, I. (2015). Searching for sustainability in teacher education and educational research: Experiences from the Baltic and Black Sea Circle Consortium for educational research. Discourse and Communication for Sustainable Education, 6, 21-29.

Salite, I. (2008). Educational action research for sustainability: Constructing a vision for the future in teacher education. Journal of Teacher Education for Sustainability, $10,5-16$. 
Salīte, I., Mičule, I., Kravale, M., Iliško, D., \& Stakle, A. (2007). Toward the sustainability. Education and Sustainable Development. In A. Pipere, (Ed.)., First Steps Toward Changes (pp. 263-292). Daugavpils: Saule.

Skujiņas, V. (2000). Pedagogiijas terminu skaidrojošā vārdnīca [Glossary of pedagogical terms]. Rīga: Zvaigzne ABC.

Shank, M. (2016). Imagination, Waldorf, and critical literacies: Possibilities for transformative education in mainstream schools. Reading \& Writing, 7(2), 9. doi: 10.4102/ rw.v7i2.99.

Šlahova, A., \& Čačka, M. (2009). Development of creative activity of prospective visual art teachers. Journal of Teacher Education for Sustainability, 51-67.

Šḷahova, A., Savvina, J. Cacka, M., \& Volonte, I. (2007). Creative activity in conception of sustainable development education. International Journal of Sustainability in Higher Education, 8(2), 142-154.

Шоттенлоэр, Г. (2001). Рисунок и образ в гештальтерапии [Drawing and Image in Gestalt Therapy]. СПб: Издательство Пирожкова.

Svence, G. (1999). Attīstības psihologija [Psychology of development]. Rīga: Zvaigzne $\mathrm{ABC}$.

Tanaka, C., \& Sakuma, H. (2004). Human figure drawing size and body image in preschool children from a self-physique perspective. Perceptual and motor skills, 691-700.

Troncone, A. (2014). Problems of "draw-a-person: a quantitative scoring system" as a measure of intelligence. Psychological Reports: Measures \& Statistics, 115 (2), 485-498.

Vahter, E. (2016). Looking for a possible framework to teach contemporary art in primary school. International Journal of Art \& Design Education, 35(1), 51-67.

Varzim, M. (2005). Creativity - stimulus for human development. Kürybos Erdves. The Spaces of Creation, 2, 110-115.

Correspondence concerning this paper should be addressed to prof. Aleksandra Šlahova, Daugavpils University, Latvia. Email: aleksandra.slahova@du.lv 